\title{
Gebelik Seyrinde Subakut Tiroidit: Olgu Sunumu
}

Subacute Thyroiditis During Pregnancy: A Case Report

\author{
Canan Akkuş ${ }^{1}$ iD, Cevdet Duran ${ }^{2}$
}

1 İç Hastalıkları Kliniği, Uşak Eğitim ve Araştırma Hastanesi, Uşak/Türkiye 2 Endokrinoloji ve Metabolizma Hastalıkları Bilim Dalı, İç Hastalıkları Anabilim Dalı, Uşak Üniversitesi Tıp Fakültesi Uşak/Türkiye

\section{özeT}

Subakut tiroidit (SAT) veya De Quervain tiroiditi, tiroid bozukluğunun geçici bir formu olup, viral enfeksiyonlardan sonra gelişen tiroid bezi inflamasyonu ile karakterizedir. Bu hastalık kadınlarda, özellikle de mevsimsel geçiş dönemlerinde daha yaygındır. Sıklıkla trifazik bir seyir göstermesine rağmen, bazı hastalarda kalıcı hipotiroidizm gelişebilir. Hastalık kişiden kişiye değişebilir ve bazı hastalarda çok şiddetli seyredebilir. Gebelik esnasında SAT gelişimi nadirdir ve hamilelik sonucunu etkileyebilir. Bu yazıda, hamilelik sırasında SAT gelişen ve gebeliğin 21. haftasında erken membran rüptürü nedeniyle ölü doğum gelişen bir hasta sunduk.

Anahtar Kelimeler: gebelik, tiroidit, subakut tiroidit

\section{ABSTRACT}

Subacute thyroiditis (SAT) or De Quervain thyroiditis is a temporary form of thyroid disorder and characterized by thyroid gland inflammation developing after viral infections. The disease is more commonly encountered in women, especially during seasonal transition periods. Although the condition often shows a triphasic course, some patients may develop permanent hypothyroidism. The disease may differ from person to person and be severe in some patients. The development of SAT during pregnancy iş rare and could affect the pregnancy outcomes. In this article, we present a patient developing SAT during pregnancy and the occurrence of a stillbirth due to early membrane rupture in 21st week of gestation.

Keywords: pregnancy, thyroiditis, subacute thyroiditis

\section{Giriş}

Gebelik seyrinde, gebelerin yaklaşık \% 0.2 ila \% 0.7'sinde tirotoksikoz gelişmektedir $(1,2)$. Basedow-Graves Hastalı̆̆ı, hiperemezis gravidarum ve buna bağlı geçici gestasyonel tirotoksikoz gebelik sırasında ortaya çıkan tirotoksikoz olgularının çoğunluğunu oluşturur (2). Gebelikte tirotoksikozun nadir sebeplerinden biri de SAT'tır $(3,4)$. Subakut tiroidit genellikle kadınlarda, viral enfeksiyonlar sonrası ve mevsimsel geçiş dönemlerinde gelişen tiroid bezi inflamasyonu ile karakterize bir hastalıktır (5). Subakut tiroidit olgularının çoğu tedavi olmadan kendiliğinden düzelse de, gebelikte ortaya çıkabilecek komplikasyonlar göz önüne alınmalı ve her hasta ayrı ayrı değerlendirilerek tedavi edilmelidir. Biz bu yazımızda, hamilelik sırasında SAT gelişen ve gebeliği erken membran rüptürü nedeniyle 21 . gebelik haftasında ölü doğumla sonlanan bir olguyu sunduk.

\section{OLGU}

37 yaşında, daha önceden hipotiroidi nedeniyle $75 \mu \mathrm{g}$ Ltiroksin alan kadın hasta gebeliğin 6 . haftasında ateş ve boğaz ağrısı yakınmalarıyla dahiliye polikliniğimize başvurmuş. Yapılan tetkiklerde tiroid stimülan hormon (TSH) düşüklüğü ve serbest T4 yüksekliği saptanması üzerine endokrinoloji polikliniğine yönlendirilmiş. Gebeliğinin 7. haftasında endokrinoloji polikliniğimize başvuran hasta kulaklara vuran boğaz ağrı tarif ediyordu. Son 1 haftadır L-tiroksin almayan hastanın fizik muayenesinde tremor, taşikardi ve tiroid bezinde palpasyonda hassasiyet saptandı. Hastanın ateşi yüksek değildi. Hastanın tiroid ultrasonografisi (USG) SAT ile uyumluydu. Klinik olarak SAT düşünülen hastada laboratuvar testlerinde TSH: $0.129 \mathrm{mIU} / \mathrm{L}(\mathrm{N}:$ 0.55-4.78 $\mathrm{mIU} / \mathrm{L})$, serbest T4: $2.11 \mathrm{ng} / \mathrm{dL}(\mathrm{N}: 0.85-1.6 \mathrm{ng} / \mathrm{dL})$, serbest T3 $4.3 \mathrm{ng} / \mathrm{L}$ (N: 2.3-4.2 ng/L), eritrosit sedimantasyon hızı (ESR) $105 \mathrm{~mm}$ (N: 0-20 mm), c-Reaktif Protein (cRP) 177.4 mg/L (0.1-5 mg/L) olarak saptandı (Tablo 1). Anti tiroglobulin

Yazışma Adresi/Address for Correspondence: Cevdet Duran, MD Uşak Üniversitesi Tıp Fakültesi, İç Hastalıkları Anabilim Dalı, Endokrinoloji ve Metabolizma Hastalıkları Bilim Dalı, 64200, Uşak /Türkiye

E-Posta/E-Mail: drcduran@gmail.com || Tel: +90 5334298585

Received/Geliş Tarihi: 19.06.2020 || Accepted/Kabul Tarihi: 21.07.2020

Bu Eser Creative Commons Atıf-Gayriticari 4.0 Uluslararası Lisansı İle Lisanslanmıştır. This work is licensed under a Creative Commons

Attribution-NonCommercial 4.0 International License (CC BY-NC 4.0). 
antikor, anti TPO ve tiroid stimüle edici immünglobülin düzeyleri negatifti. Hastanın kliniği ve laboratuvar sonuçları SAT ile uyumluydu. Tedavi olarak hastaya parasetamol 4x500 mg, oral başlandı. Bu tedavi ile şikayetleri gerileyen hastanın Mayıs 2019'da gebeliğinin 11. haftasında yapılan tetkiklerinde TSH: $21.67 \mathrm{mIU} / \mathrm{L}$ ve serbest T4: $1.25 \mathrm{ng} / \mathrm{dL}$ olarak saptandı. Hastaya $75 \mu \mathrm{g}$ oral L-tiroksin başlandı ve kontrol TSH ve tiroid hormon düzeylerine göre ilaç dozu günlük $150 \mu \mathrm{g}$ 'a kadar çıkıldı. Obstetrik takipleri normal seyreden hastada Temmuz 2019'da gebeliğin 21. haftasında erken membran rüptürü gelişti ve gebelik ölü doğumla sonlandı. Ölü doğum sonrası takiplerinde hipotiroidisi devam eden ve günlük $175 \mu \mathrm{g}$ L-tiroksin tedavisine devam edilen hastada en son Haziran 2020'de bakılan tetkiklerinde tiroid hormonlar ötiroidik idi.

Tablo 1: Olgunun bazı hormon ve inflamatuvar belirteçlerinin zamanla seyri.

\begin{tabular}{|c|c|c|c|c|c|c|}
\hline & TSH & ST4 & ST3 & ESR & cRP & Tedavi \\
\hline $\begin{array}{r}\text { Gebeliğin } 7 . \\
\text { Haftası }\end{array}$ & 0.13 & 2.11 & 4.38 & 105 & 177.4 & $\begin{array}{c}\text { Parasetamol } \\
4 \times 500 \mathrm{mg}\end{array}$ \\
\hline $\begin{array}{r}\text { Gebeliğin } 9 . \\
\text { Haftası }\end{array}$ & 0.10 & 1.74 & & 99 & 28.1 & $\begin{array}{c}\text { Parasetamol } \\
4 \times 500 \mathrm{mg}\end{array}$ \\
\hline $\begin{array}{r}\text { Gebeliğin } 11 . \\
\text { Haftası }\end{array}$ & 21.67 & 1.13 & & 85 & 18.6 & $75 \mu \mathrm{g}$ L-T4 \\
\hline $\begin{array}{r}\text { Gebeliğin } 14 . \\
\text { Haftası }\end{array}$ & 28.34 & 1.25 & 2.54 & 95 & 29.1 & $100 \mu \mathrm{g}$ L-T4 \\
\hline $\begin{array}{r}\text { Gebeliğin } 16 . \\
\text { Haftası }\end{array}$ & 12.38 & 1.20 & & & & $150 \mu \mathrm{g} \mathrm{L-T4}$ \\
\hline $\begin{array}{r}\text { Gebeliğin } 20 . \\
\text { Haftası }\end{array}$ & 5.24 & 1.79 & & 77 & 28.5 & $150 \mu \mathrm{g}$ L-T4 \\
\hline $\begin{array}{r}\text { Ölü } \\
\text { doğumdan } 1 \\
\text { ay sonra }\end{array}$ & 0.03 & 1.53 & & 45 & 6.5 & $100 \mu \mathrm{g}$ L-T4 \\
\hline $\begin{array}{r}\text { Ölü } \\
\text { doğumdan } 2 \\
\text { ay sonra }\end{array}$ & 25.10 & 1.03 & & 27 & 5.3 & $150 \mu \mathrm{g} \mathrm{L-T4}$ \\
\hline $\begin{array}{r}\text { Ölü } \\
\text { doğumdan } 11 \\
\text { ay sonra }\end{array}$ & 1.48 & 1.37 & & & & $150 \mu \mathrm{g}$ L-T4 \\
\hline
\end{tabular}

\section{SONUÇ}

Bu yazımızda hamilelik sırasında SAT gelişen ve gebeliği 21 . gebelik haftasında erken membran rüptürü nedeniyle ölü doğumla sonlanan bir olguyu sunduk. Gebelik hiperdinamik ve hipermetabolik bir süreç olup, sıklıkla bulguları tirotoksikozla karışabilir. Gebelik sırasında ilk trimesterde olguların yaklaşık \%20-30'unda human koriyonik gonadotropin düzeylerindeki artışa bağı fizyolojik olarak TSH düşüklüğü olabileceği, bazı olgularda da serbest tiroid hormonlarında yükselmesiyle geçici gebelik tirotoksikozuna neden olabileceği bilinmektedir (6-8). Gebelik esnasında zeminde bulunan bir Graves hastalığı da gebelik esnasında tirotoksikoza neden olabilir. Gebelik esnasında SAT'a bağlı tirotoksikoz oldukça nadirdir $(3,4)$. SAT kendisine özgü klinik ve laboratuvar ile kolayca ayırt edilebilse de bazı hastalarda semptomlar silik olabilir ve tanıda zorluk yaşanabilir (5). Hipertiroidisiz tirotoksikoz tanısında yardımcı olacak iyot uptake'i gibi sintigrafik görüntüleme yöntemlerinin gebelik durumunda kullanılamaması bazı hastalarda ayırıcı tanıda önemli bir handikaptır. Ancak tipik kliniğinden dolayı çoğu olguda SAT tanısı koymak kolaydır. Sunulan olguda daha önceden ateş yakınması olsa da bize başvurduğunda ateşi yoktu, bu nedenle biz hastaya sadece parasetamol verdik. Bize başvurmadan önce L-tiroksin alan hastada aşikar tirotoksikoz gelişmesi nedeniyle L-tiroksin tedavisi kesilmişti. Olası bir Graves açısından bakılan tiroid stimülan immünglobülin düzeyleri negatifti. Literatürde belirtilen sınırlı sayıdaki SAT ve gebeliğin olduğu olgularda, gebelik nedeniyle tedavide antiinflamatuvar olarak nonsteroid ilaçlar kullanılamamış, bunun yerine gerekli durumlarda prednizolon tedavisi kullanılmış ve gebelik sonuçları olumlu bildirilmiştir $(3,4)$. Anastasilakis ve ark. gebeliğin ilk trimesterinde biyopsi ile kanıtlanmış SAT tanısı koydukları bir hastalarının steroid almadan düzeldiğini, gebeliğin kalan kısmını L-tiroksin replasmanı ile tamamladığını bildirmişlerdir (3). Diğer bildirim Hiraiwa ve ark. tarafından, her ikisi de gebeliğin ilk trimesterinde tanı alan, biri hafif, biri de şiddetli iki SAT vakası bildirilmiş olup, hafif SAT vakasının tedavi almadan düzeldiği, şiddetli SAT vakasının ise steroid tedavisi aldığı ve her iki gebeliğin de miadında sağlıklı doğum ile sonuçlandığını bildirmişlerdir (4). Bizim hastamızda 7 haftada $177 \mathrm{mg} / \mathrm{L}$ olan CRP düzeyleri 9. haftada $28 \mathrm{mg} / \mathrm{L}$. ye, 11 haftada $18 \mathrm{mg} / \mathrm{L}$ ye geriledi. Klinik şiddetli olmadığı için steroid tedavisine ihtiyacı olmadı, hatta tedavide başlanan parasetamole bile nadiren ihtiyacı oldu. Daha önceden L-tiroksin alan ve tedavisi kesilen hasta ikişer hafta gibi sık periyotlarda kontrole çağrıldı, ancak Ltiroksin kesildikten 5 hafta sonra hastalık hipotiroidik faza girdi ve yeniden L-tiroksin başlandı. 21. gebelik haftası civarı, günlük $150 \mu \mathrm{g}$ L-tiroksin tedavisi altında ve TSH 5.5 mIU/L civarında iken erken membran rüptürü ve buna bağlı ölü doğum oldu. 
Subakut tiroidit trifazik bir seyir gösterse de bazı olgularda kalıcı hipotiroidi gelişebilir. Sunulan olguda hastalığın başlangıcından itibaren 15 ay geçmesine rağmen hala 175 $\mu \mathrm{g}$ L-tiroksin alıyordu ve ötiroidi ancak bu tedavi ile sağlanabiliyordu. Subakut tiroidit gelişmeden önce de uzun yıllar L-tiroksin alan hastada bu durum kalıc hipotiroidi olarak kabul edildi ve düzenli poliklinik kontrolü planlandı.

Sonuç olarak gebelik esnasında tirotoksikoz gelişen olgularda nadir nedenlerden birisi de SAT olup, gebelik sonuçları üzerine olumsuz etkileyebilir. Subakut tiroidit gelişen hastalarda tirotoksikoz dışında hastalık esnasındaki meydana gelen artmış inflamasyonunda gebelik sonuçları üzerine olumsuz etkisi olabilir. Bu bilgilerin başka çalışmalarla da desteklenmesi gerekir.

Etik; Bu yazıda sunulan olgu için sunulan bilgilerin akademik amaçı kullanımı hakkında detaylı bilgileri de içeren imzalı "Bilgilendirilmiş onam formu" alınmıştır.

Ethics; For the case presented in this article, a signed "informed consent form" was obtained, which includes detailed information about the use of the information presented for academic purposes.

Yazar katkı durumu; Olgunun tanı ve takip süreci; CA, CD tedavi süreci; $C A, C D$ Literatür taraması $C A, C D$ yazım aşaması; CA, CD

Author contribution status; The concept of the study; CA, CD design; CA, CD literature review; $C A, C D$ collecting and processing data; $C A, C D$ statistics; $C A, C D$ writing phase; $C A$, CD

Yazarlar arasında çıkar çatışması yoktur.

The author declares no conflict of interest.

Finansal Destek: yoktur / Funding : none

doi: https://doi.org/10.33713/egetbd. 755290

\section{KAYNAKLAR}

1. Dong AC, Stagnaro-Green A. Differences in diagnostic criteria mask the true prevalence of thyroid disease in preg-nancy: a systematic review and meta-analysis. Thyroid 2019;29:278-289.

2. American College of Obstetricians and Gynecologists. Practice bulletein No.148: Thyroid disease in pregnancy. Obstet Gynecol. 2015;125:996-1005.

3. Anastasilakis AD, Karanicola V, Kourtis A, et al. A Case Report of Subacute Thyroiditis During Pregnancy: Difficulties in Differential Diagnosis and Changes in Cytokine Levels. Gynecol Endocrinol. 2011;27:384-390
4. Hiraiwa T, Kubota S, Imagawa A, et al. Two Cases of Subacute Thyroiditis Presenting in Pregnancy. J Endocrinol Invest. 2006;29:924-927

5. Samuels MH. Subacute, silent, and postpartum thyroiditis. Med Clin North Am. 2012;96:223-233

6. Sterrett M. Maternal and Fetal Thyroid Physiology. Clin Obstet Gynecol. 2019;62:302-307

7. Thyroid Disease in Pregnancy: ACOG Practice Bulletin, Number 223. Obstet Gynecol. 2020;135:e261-e274

8. Yeo CP, Khoo DH, Eng PH, Tan HK, Yo SL, Jacob E. Prevalence of gestational thyrotoxicosis in Asian women evaluated in the 8th to 14th weeks of pregnancy: correlations with total and free beta human chorionic gonadotrophin. Clin Endocrinol (Oxf). 2001;55:391-398. 